\title{
Vaspin in the pig ovarian follicles: expression and regulation by different hormones
}

\author{
Patrycja Kurowska, Ewa Mlyczyńska, Alix Barbe², Christophe Staub³ , Ewa Gregoraszczuk¹, \\ Joëlle Dupont ${ }^{2}$ and Agnieszka Rak ${ }^{1}$ \\ ${ }^{1}$ Department of Physiology and Toxicology of Reproduction, Institute of Zoology and Biomedical Research, \\ Jagiellonian University in Krakow, Krakow, Poland, ${ }^{2}$ INRA, UMR85, Unité Physiologie de la Reproduction et des \\ Comportements, Nouzilly, France and ' INRA-Unité Expérimentale de Physiologie Animale de l'Orfrasière UEPAO \\ 1297, Nouzilly, France
}

Correspondence should be addressed to A Rak; Email: agnieszka.rak@uj.edu.pl

\begin{abstract}
Vaspin, also known as visceral adipose tissue-derived serine protease inhibitor, is a member of the serine protease inhibitor family. Its expression is associated with obesity, insulin resistance and type 2 diabetes, and elevated concentration is observed in polycystic ovary syndrome. However, vaspin has never been studied in the ovary. Here, we identified vaspin in two prolific breeds of pigs: fat Meishan (MS) and lean Large White (LW). We then investigated the molecular mechanism involved in the regulation of its expression in response to gonadotropins, insulin, insulin-like growth factor type 1 (IGF-1) and steroids (progesterone, testosterone and oestradiol) in ovarian follicles cells. Using real-time PCR and Western blot, we found higher vaspin mRNA and protein expression in the ovarian follicles and adipose tissue at 10-12 days of the oestrous cycle in MS compared to LW. Moreover, vaspin expression, as well as its concentration in plasma and follicular fluid, decreased in ovarian follicles of LW during days of the oestrous cycle, while the opposite results were noted in MS. Immunohistochemistry showed vaspin in granulosa, theca, cumulus cells and oocytes as well as in adipocytes. Vaspin level in the ovary increased by gonadotropin, insulin, IGF-1 and steroids stimulation through kinases JAK/Stat, ERK1/2, PI3K and AMPK, as well as factor NF-KB. These findings all show vaspin expression and regulation in the pig ovary, indicating vaspin as a new regulator in female reproduction. Future studies will be necessary for understanding the role of vaspin on ovarian physiology providing new insights into the pathology of ovaries.
\end{abstract}

Reproduction (2019) 158 135-146

\section{Introduction}

Vaspin is known as a visceral adipose tissue-derived serine protease inhibitor and is a member of the serine protease inhibitor family which has insulin-sensitising effects (Hida et al. 2005). Rat, mouse and human vaspins are made up of 392, 394 and 395 amino acids, respectively. They exhibit approximately $40 \%$ homology with $\alpha 1$-antitrypsin and are related to the serine protease inhibitor family. The gene that encodes for vaspin is termed $O L-64$ and is present at the long arm of chromosome $14(14 q 32.1)$ where the cDNA consists 1245 bases and encodes for 415 amino acids (Hida et al. 2000, 2005). Vaspin is located in visceral white adipose tissue (WAT) of Otsuka Long-Evans Tokushima Fatty (OLETF) rat, an animal model characterised by abdominal obesity with type 2 diabetes (Hida et al. 2005). Expression of vaspin is also found in gastric mucosa, liver, pancreas, cerebrospinal fluid, skin and in the experimental models of obese $d b / d b$ and lean C57BL/6 mice (Klöting et al. 2011). Vaspin mRNA expression is regulated by nutritional status, metformin, gender and pituitary factors in rat WAT (González et al. 2009). Moreover, pioglitazone significantly induced vaspin levels in adipose 3T3-L1 cells (Handisurya et al. 2010), and rosiglitazone in brown adipose tissue (Weiner et al. 2017).

Vaspin has also been linked to metabolic syndrome (Heiker 2014) and ovarian pathology such as polycystic ovary syndrome (PCOS), because serum levels of vaspin are enhanced in PCOS patients (Tan et al. 2008, Koiou et al. 2011a, Cakal et al. 2011). It is important to note that PCOS is often associated with insulin resistance, obesity or type 2 diabetes (Rojas et al. 2014), i.e. parameters with direct effects on vaspin levels and the variability in the data may arise from homogenous study cohorts and apply diagnostic criteria (Koiou et al. 2011b). Plasma vaspin levels are higher in women than in men (Youn et al. 2008, González et al. 2009), suggesting a possible involvement of sex steroids in regulating vaspin production. However, the vaspin expression, regulation and physiological role in the female reproduction have still not been determined. 
It is a well-known fact that adipokines regulate female reproduction and more precisely, the ovarian follicles function (Tersigni et al. 2011). Additionally, increasing evidence shows that the dysregulated ovarian expression of adipokines plays an important role in the pathology of PCOS. For example, apelin and its receptor APJ are expressed in ovarian follicle cells, including theca (Tc), granulosa (Gc) and oocyte of different species such as porcine, bovine, rhesus monkey and human (Shirasuna et al. 2008, Schilffarth et al. 2009, Xu et al. 2012, Rak et al. 2017a, Roche et al. 2017). Moreover, ovarian expression of adipokines is dependent on hormonal status. Progesterone (P4) and folliclestimulating hormone (FSH) stimulated the expression of APJ in the cultured Gc, while luteinising hormone (LH) induced the expression of apelin/APJ in cultured Tc (Shimizu et al. 2009). Resistin and adiponectin are also expressed in the ovarian cells, and several studies have shown their effect on follicular development, steroidogenesis, proliferation/apoptosis and oocyte maturation (Pierre et al. 2009, Richards et al. 2012, Rak et al. 2015a, 2017b).

Thus, the aim of this study was to identify vaspin expression in the porcine ovarian follicles and WAT at 10-12 days of the oestrous cycle. Next, vaspin concentration in plasma and follicular fluid (FF) as well as vaspin expression in the ovarian follicles during the oestrous cycle were analysed. For animal models, we used two prolific breeds of pigs: fat Meishan (MS) and lean Large White (LW), differing in fat content (MS > LW). The Chinese MS breed is one of the most prolific pig breeds known, farrowing between three and five more live piglets per litter than European commercial breeds, such as the LW. However, the MS is not commercially viable in Europe due to its poor growth rate and high carcass fat content (Bidanel et al. 1990, Haley et al. 1992, Serra et al. 1992). In the next part of our study, we investigated the regulation of vaspin expression by gonadotropin, insulin, insulin-like growth factor 1 (IGF-1) and steroid hormones such as P4, testosterone (T) and oestradiol (E2) in vitro coculture of granulosa and theca cells. In mammals, gonadotropin, insulin, IGF-1 and steroids are well known to play a key role on oestrous cycle regulation, ovarian cells activity i.e. folliculogenesis, steroidogenesis, cell proliferation and ovulation (Silva et al. 2009). We investigated whether vaspin expression and secretion are dependent on the activation of several kinases such extracellular signal-regulated kinase (ERK1/2), phosphatidylinositol 3'-kinase (PI3K)/Akt, Janus kinase/signal (Stat/JAK2), adenosine $5^{\prime}$-monophosphate-activated protein kinase $\alpha$ (AMPK $\alpha$ ) and nuclear factor- $\mathrm{kB}(\mathrm{NF}-\kappa \mathrm{B})$. We chose these kinases because their phosphorylation is important in the regulation of adipokines expression. For example, $17 \beta$-E2 stimulates (Chen et al. 2006) but IGF-1 inhibits (Chen et al. 2005) resistin gene expression in 3T3-L1 adipocytes via ERK1/2 pathway.

\section{Materials and methods}

\section{Reagents}

Foetal bovine serum (FBS, heat inactivated) and electrophoresis marker were purchased from ThermoFisher Scientific. Phosphate buffered saline (PBS) was purchased from BioWest (Riverside, MO, USA). Medium M199, antibiotic-antimycotic solution, Tris, trypsin, FSH (cat no. F4021), LH (cat no. L5259), IGF-1 (cat no. 13769), insulin (cat no. I3505), P4, T, E2 (cat no. P0130, 86500 and E2257, respectively), AG 490 (cat no. T3434), Compound C (cat no. P5499), JSH-23 (cat no. J4455) and Laemmli buffer (cat. no. 38733) were all obtained from Sigma-Aldrich. PD98059 (cat no. 1213) was obtained from Tocris and LY294002 (cat no. 9901) from Cell Signaling Technology. Bradford protein assay kit, 4-20\% gels (cat no. 456-1093) and membranes (cat no. 1704156) were obtained from Bio-Rad.

\section{Sample collection}

Porcine ovarian follicles, WAT around the kidney and plasma were collected from MS and LW sexually mature pigs at a local abattoir under veterinarian control, less than $20 \mathrm{~min}$ after slaughter. LW gilts with an average weight of $91.76 \pm 8.2 \mathrm{~kg}$ and the same number of MS gilts with an average body weight of $30.62 \pm 5.8 \mathrm{~kg}$ were used in this study. Tissues were transported to the laboratory in PBS with antibiotic-antimycotic solution within $30 \mathrm{~min}$ of collection. Ovarian follicles, FF and blood samples were collected from $36 \mathrm{LW}$ and $36 \mathrm{MS}$ pigs on days 4-6 $(n=12), 10-12(n=12)$ and $16-18(n=12)$ of oestrous cycle by morphological examination of the ovaries (Akins \& Morissette 1968), while WAT, used as a positive control, was collected at days 10-12 of oestrous cycle. To determine vaspin mRNA expression, ovarian follicles, after excision from the ovary, and WAT were immediately frozen in liquid nitrogen and stored at $-70^{\circ} \mathrm{C}$. To quantify vaspin protein expression, tissues were homogenised twice in ice-cold lysis buffer. Lysates were cleared by centrifugation at $15,000 \mathrm{~g}$ at $4{ }^{\circ} \mathrm{C}$ for $30 \mathrm{~min}$, and the protein contents were determined by a protein assay using bovine serum albumin as a standard (Bradford method). Ovarian follicles and WAT at days 10-12 of oestrous cycle were fixed in $4 \%$ paraformaldehyde, dehydrated in an increasing gradient of ethanol, and then embedded in paraplast for vaspin analysis by immunolocalisation. Both FF and plasma samples were prepared by low-speed centrifugation $\left(2,000 \mathrm{~g}\right.$ at $4^{\circ} \mathrm{C}$ for $\left.10 \mathrm{~min}\right)$ and stored at $-20^{\circ} \mathrm{C}$ to determine the vaspin concentration.

\section{Ovarian cells in vitro culture}

Ovarian Gc and Tc were subsequently prepared from the follicles at days 10-12 of oestrous cycle of LW pigs. Gc and TC from the same follicles were prepared by technique described by Stoklosowa et al. (1978). The coculture model of both cell types in ovarian follicles is better than a monoculture of one cell type because all interaction (structural and functional) between Gc and Tc cells are preserved in vitro. This in vitro model was used in previous studies examining the role of IGF1 , ghrelin and adipokines in the porcine ovary (Kolodziejczyk 
et al. 2003, Rak \& Gregoraszczuk 2008, 2015a, Rak-Mardyla \& Gregoraszczuk 2010). Herein, viability (Trypan blue exclusion test) was found to be $92 \%$ for Gc and $84 \%$ for Tc. For coculture experiments, Gc and Tc were inoculated at concentrations of $6 \times 10^{4}$ and $1.5 \times 10^{4}$ cells/well, respectively, in 96-well tissue culture plates. Therefore, the ratio of both types of cells was comparable to that observed in vivo $(\mathrm{Gc}: \mathrm{Tc}=4: 1)$. All cultures were maintained at $37^{\circ} \mathrm{C}$ in a humidified atmosphere of $5 \%$ $\mathrm{CO}_{2} / 95 \% \mathrm{O}_{2}$.

For the determination of the regulation of vaspin expression, ovarian cells were incubated for $48 \mathrm{~h}$ in M199 supplemented with $5 \%$ FBS as a control medium or with $\mathrm{FSH}$ or $\mathrm{LH}$ at $50-150 \mathrm{ng} / \mathrm{mL}$, insulin or IGF-1 at $10-100 \mathrm{ng} / \mathrm{mL}$ and steroids $\mathrm{P} 4, \mathrm{~T}$ or $\mathrm{E} 2$ at $10^{-8}-10^{-6} \mathrm{M}$. Doses of hormones were chosen based on literature and our previous study (Rak et al. 2015b). After incubation, medium was stored at $-20^{\circ} \mathrm{C}$ for vaspin concentration, while the cells were boiled in Laemmli buffer for $4 \mathrm{~min}$ and then stored at $-20^{\circ} \mathrm{C}$ for vaspin protein expression analysis. We performed four independent culture. For one culture we used ovarian cells collected from seven pigs (ten follicles from one pig, per each hormone: control and three doses, in single repetition), so the total number of pigs was 28.

To investigate whether vaspin expression is dependent on kinases activation, cells were plated in 96-well culture plates in M199 medium with 10\% FBS for $24 \mathrm{~h}$. Next, the media were changed to $5 \%$ FBS and the cells were pre-treated for $1 \mathrm{~h}$ with the JAK inhibitor AG490 at $50 \mu \mathrm{M}$, the ERK1/2 inhibitor PD098059 at $50 \mu \mathrm{M}$, the PI3K inhibitor LY294002 at $10 \mu \mathrm{M}$, the AMPK $\alpha$ inhibitor compound $\mathrm{C}$ at $10 \mu \mathrm{M}$ and the NF-кB inhibitor $\mathrm{JSH}-23$ at $50 \mu \mathrm{M}$. Then, gonadotropins at $100 \mathrm{ng} / \mathrm{mL}$, insulin or IGF-1 at $50 \mathrm{ng} / \mathrm{mL}$ and steroids at $10^{-7} \mathrm{M}$ were added for $48 \mathrm{~h}$. The concentrations of the inhibitors were chosen based on previous data (Rak et al. 2015b) and an unpublished study. After incubation, medium was stored at $-20^{\circ} \mathrm{C}$ for vaspin concentration, while the cells were boiled in Laemmli buffer for $4 \mathrm{~min}$ and then stored at $-20^{\circ} \mathrm{C}$ for vaspin protein expression analysis. We performed five independent culture. For one culture we used ovarian cells collected from 14 pigs (20 follicles from two pigs, per each hormone: control and three doses, in single repetition), so the total number of pigs was 70 .

\section{Real-time PCR}

Total RNA was extracted from ovarian follicles and WAT using TRIzol reagent (Reverchon et al. 2014). Reverse transcription procedure was subsequently conducted. Briefly, $1 \mu \mathrm{g}$ of total RNA was reverse transcribed for $1 \mathrm{~h}$ at $37^{\circ} \mathrm{C}$ in a final reaction volume of $20 \mu \mathrm{L}$, containing $50 \mathrm{mM}$ Tris- $\mathrm{HCl}(\mathrm{pH} 8.3)$, $75 \mathrm{mM} \mathrm{KCl}, 3 \mathrm{mM} \mathrm{MgCl}, 200 \mu \mathrm{M}$ of each deoxynucleotide triphosphate (Amersham, Piscataway, NJ, USA), $50 \mathrm{pmol}$ of oligo(dT) 15, $5 \mathrm{U}$ of ribonuclease inhibitor and $15 \mathrm{U}$ of MMLV reverse transcriptase. Afterwards, porcine cDNA was diluted 1:5.

Real-Time PCR was performed in a $20 \mu \mathrm{L}$ final volume containing $10 \mu \mathrm{L}$ iQ SYBR Green supermix (Bio-Rad), $0.25 \mu \mathrm{L}$ of each primer $(10 \mu \mathrm{M}), 4.5 \mu \mathrm{L}$ of water and $5.0 \mu \mathrm{L}$ of template. The CDNA templates were amplified and detected using the MYIQ Cycler real-time PCR system (Bio-Rad) following the protocol previously described by Rak et al. (2017a). The abundance of housekeeping gene PPIA (cyclophilin A) was examined and normalised according to Vandesompele et al. (2002). The descriptions of the different primers are as follows: Vaspin (SERPINA12) (forward 5'-GCTGTGAGTCGTGACCAAGT-3' and reverse 5'-CACAGAGATGCTCCAAGGG-3') and PPIA (forward 5'-GCATACAGGTCCTGGCATCT-3' and reverse 5'-TGTCCACATGCAGCAATGGT- $3^{\prime}$ ). The specificity of the amplified fragment sequence was assessed by Beckman Coulter Genomics. The efficiency was between 1.8 and 2.0.

\section{Western blot}

Tissue preparation, lysis, Western blotting and quantification were performed as previously described (Rak et al. 2015a,b). For each sample, $30 \mu \mathrm{g}$ of protein were reconstituted directly in the appropriate amount of sample buffer and separated in Mini-Protean TGX System Precast Protein Gels (Bio-Rad), and then transferred to Trans-Blot Turbo Mini PVDF Transfer Packs (Bio-Rad). The membranes were washed and blocked in $0.02 \mathrm{M}$ Tris-buffered saline containing $5 \%$ BSA and $0.1 \%$ Tween 20, and then incubated overnight at $4{ }^{\circ} \mathrm{C}$ with antivaspin antibody (cat no. PA5-30989, ThermoFisher Scientific) diluted at 1:1,000. Next, the membranes were washed with TBST (Tris-buffered saline containing $0.1 \%$ Tween 20) and incubated for $1 \mathrm{~h}$ with a horseradish peroxidase-conjugated antibody (cat. no. 7074, Cell Signaling Technology) diluted at $1: 1000$. An anti- $\beta$-actin antibody (cat no. A5316, SigmaAldrich) was used as loading control. Signals were detected by chemiluminescence using WesternBright Quantum HRP substrate (cat. no. K-12043 D20, Advansta Inc., Menlo Park, USA) and visualised using the Chemidoc ${ }^{\mathrm{TM}}$ XRS + System (BioRad). All visible bands were quantified using a densitometer and ImageJ software (US National Institutes of Health).

\section{Immunohistochemistry}

To determine vaspin localisation in the ovary or WAT, immunohistochemistry was applied (Reverchon et al. 2014). Sections ( $5 \mu \mathrm{m}$ thick) were mounted onto APES-coated slides, deparaffinised in xylene, and then gradually rehydrated through a series of ethanol dilutions. The sections were immersed in $0.01 \mathrm{M}$ citrate buffer and heated in a microwave oven for antigen retrieval. Endogenous peroxidase activity and nonspecific binding were blocked. Next, the sections were incubated overnight at $4{ }^{\circ} \mathrm{C}$ with anti-vaspin antibody (cat no. PA5-30989, ThermoFisher Scientific) then washed in TBST. After, they were incubated with biotinylated goat anti-rabbit IgG (1:400; Vector Lab) followed by avidin-biotin-peroxidase complex (1:1:100; Strept ABC complex/HRP, DAKO/AS). The sections were dehydrated, mounted in DPX (Fluka, Chemie $\mathrm{GmbH}$, Buchs) and then photographed using the Nikon Eclipse E200 microscope attached to the Coolpix 5400 digital camera (Nikon) with corresponding software. 


\section{ELISA assay}

A commercially available pig vaspin ELISA (cat. no. MBS267502; MyBioSource, San Diego, USA) was used to quantify vaspin concentrations in plasma, FF and culture medium. The sensitivity of the vaspin assay was $0.05 \mathrm{ng} / \mathrm{mL}$, and the inter- and intra-experimental coefficients of variation were $<12$ and $<8 \%$, respectively. Samples were run in triplicate within the same assay.

\section{Statistical analysis}

Statistical data are presented as means \pm S.E.M. of four/five independent experiments performed in threefold. Distribution of normality was checked by Shapiro-Wilk test. Statistical analysis was carried out using two-way ANOVA, followed by Tukey's test (GraphPad Software) to compare vaspin levels between breeds of pigs (LW and MS) and days of the estrous cycle. A one-way ANOVA was used for multiple comparisons involving more than two treatment groups; to compare hormones/inhibitors to control or hormones+inhibitors compare to inhibitors. Statistical significance is indicated by different letters $(P<0.05)$ or by $* P<0.05,{ }^{*} * P<0.01$ and *** $P<0.001$.

\section{Results}

\section{Vaspin expression and cellular immunolocalisation in the ovarian follicles and adipose tissue as well as concentration in plasma and FF}

Comparing mRNA expression of vaspin between ovaries and WAT collected at 10-12 days of the oestrous cycle of both pig breeds, we observed significantly higher expression in MS ovarian follicles (ratio Vaspin/ PPIA mRNA expression: $1.301 \pm 0.013$ ) and WAT (ratio Vaspin/PPIA mRNA expression: $3.846 \pm 0.165$ ) compared to LW ovarian follicles $(0.0189 \pm 0.0001)$ and WAT $(0.427 \pm 0.03)(P<0.05)$; these results were confirmed on protein expression (Fig. $1 \mathrm{~A}, P<0.05$ ). Immunohistochemistry with porcine follicle sections
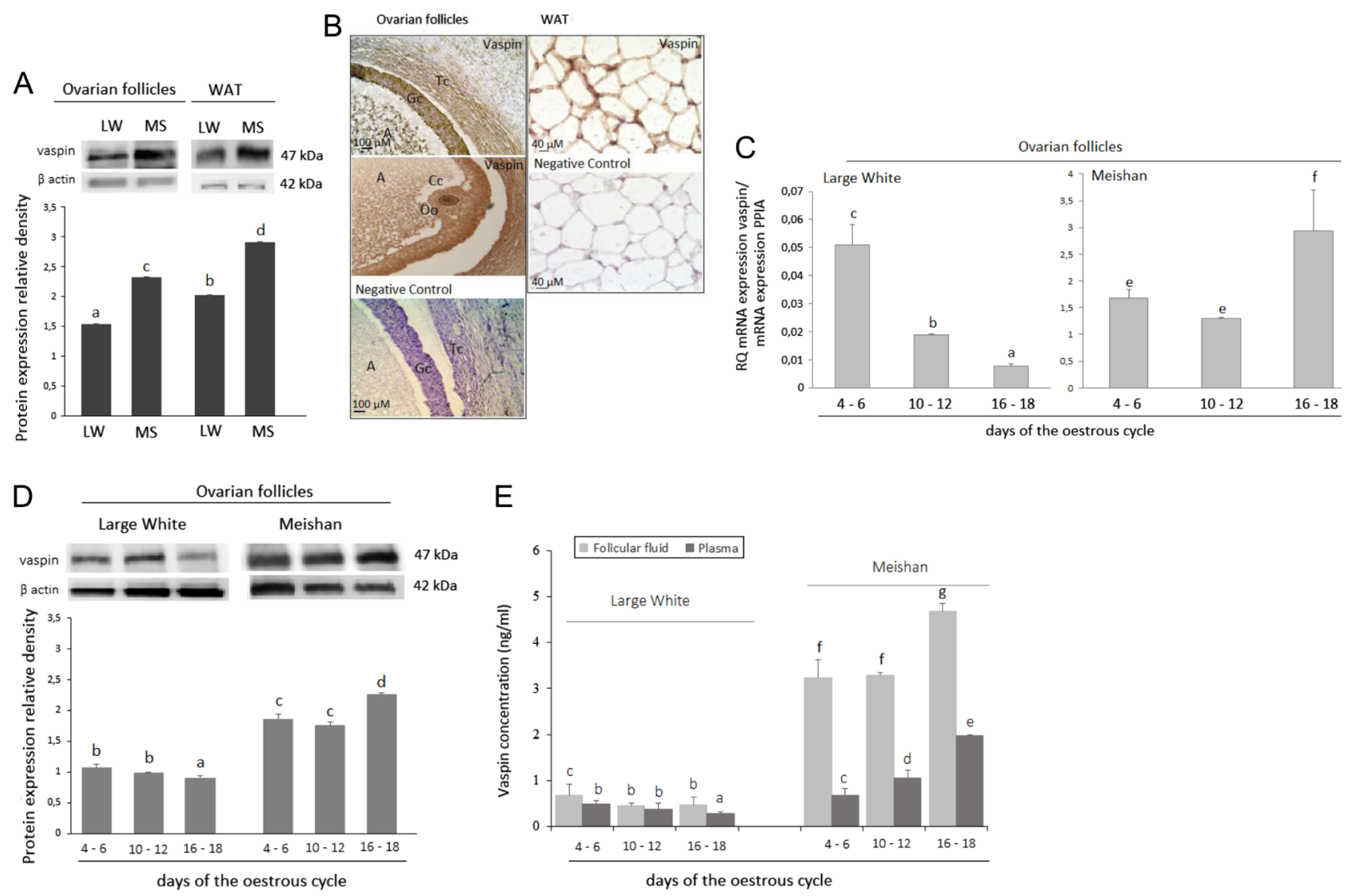

Figure 1 Vaspin levels in the ovarian follicles and visceral adipose tissue (WAT) of two pig breeds: Large White (LW) and Meishan (MS). (A) Vaspin protein expression in the ovarian follicles and WAT collected from ovarian follicles at 10-12 days of the oestrous cycle. (B) Immunolocalisation of vaspin in oocyte (Oo), granulosa (Gc), theca (Tc) and cumulus (Cc) cells of ovarian follicles and WAT collected at 10-12 days of the oestrous cycle of LW. Scale bar: $100 \mu \mathrm{M}$ for ovarian follicles and $40 \mu \mathrm{M}$ for WAT. (C) Vaspin mRNA and (D) protein expression in the ovarian follicles and (E) concentration in FF and plasma during the oestrous cycle (days 4-6, 10-12 and 16-18) in LW and MS. Figures and Images shown are representative of the four experiments on 12 LW and 12 MS different animals per stages. Statistical analysis was carried out using two-way ANOVA, followed by Tukey's test (GraphPad Software). The data are plotted as the mean \pm S.E.M. Different letters indicate significant differences at $P<0.05$. 
collected from LW showed that vaspin protein is present in Gc but also in cumulus cells, oocytes and Tc (Fig. 1B). Similar results were observed in MS ovarian cells (data not shown). We observed intense immunostaining for vaspin in WAT (Fig. 1B) collected from LW. As a negative control, we replaced the primary antibody with PBS or normal serum. No immunoreaction was observed for the negative controls. As shown in Fig. 1C, we found that mRNA expression of vaspin decreased in ovarian follicles of LW pigs during days of the oestrous cycle, while the opposite results were observed in MS pigs, where vaspin mRNA expression was significantly higher at $16-18$ days of the oestrous cycle $(P<0.05)$. Immunoblotting results confirmed the data of vaspin mRNA (Fig. 1D, $P<0.05$ ).

We also measured the concentration of vaspin in plasma and FF during the oestrous cycle. As shown in Fig. 1E, levels of vaspin in LW pigs decreased, while in MS, they increased significantly both in plasma and FF during the oestrous cycle. Furthermore, we observed that vaspin levels were higher both in plasma and FF in MS than LW pigs (Fig. $1 \mathrm{E}, P<0.05$ ). Interestingly, concentrations of vaspin were significantly higher in FF than plasma of both pig breeds, except at 10-12 days of the oestrous cycle in LW.

\section{Vaspin expression and secretion is regulated by gonadotropin, insulin, IGF-1 and steroid hormones in the ovarian follicles cells}

We observed dose-dependent effect of gonadotropin on vaspin expression in the ovarian follicles cells. FSH significantly increased vaspin protein expression at 100 and $150 \mathrm{ng} / \mathrm{mL}$. Furthermore, LH had stimulatory effect at 50 and $100 \mathrm{ng} / \mathrm{mL}$, while inhibitory at $150 \mathrm{ng} /$ $\mathrm{mL}$ (Fig. 2A, $P<0.05, P<0.01$ ). Vaspin secretion into the culture medium was significantly higher after $\mathrm{FSH}$ and $\mathrm{LH}$ stimulation, at both $100 \mathrm{ng} / \mathrm{mL}$ doses (Fig. 2A, $P<0.05)$.

After $48 \mathrm{~h}$ of ovarian cell culture, insulin at all investigated doses had stimulatory effect on vaspin protein expression and secretion to the culture medium (Fig. 2B, $P<0.05, P<0.01$ ). IGF-1 significantly stimulated vaspin protein expression at $50 \mathrm{ng} / \mathrm{mL}$ and secretion at 10 and $50 \mathrm{ng} / \mathrm{mL}$ (Fig. $2 \mathrm{~B}, P<0.05, P<0.01$ ). We documented also that IGF-1 at $100 \mathrm{ng} / \mathrm{mL}$ decreased vaspin protein expression (Fig. $2 \mathrm{~B}, p<0.05$ ).

As shown in Fig. 2C, protein expression of vaspin was strongly dependent on steroid hormones doses. We observed that P4 at $10^{-7}$ and $10^{-8} \mathrm{M}, \mathrm{T}$ at $10^{-6}$ and $10^{-7} \mathrm{M}$ and $\mathrm{E} 2$ at all investigated doses increased vaspin protein expression (Fig. $2 \mathrm{C}, P<0.01, P<0.001$ ). However, concentration of vaspin in culture medium was significantly higher after P4 at $10^{-7} \mathrm{M}, \mathrm{T}$ at $10^{-6} \mathrm{M}$ and $\mathrm{E} 2$ at $10^{-7} \mathrm{M}$ (Fig. 2C, $P<0.05, P<0.001$ ).

\section{Involvement of JAK/Stat, ERK1/2, PI3K and AMPKo kinases as well as NF-KB factor in action gonadotropin, insulin, IGF-1 and steroids on vaspin protein expression and concentration in the ovarian follicles cells}

As shown in Fig. 3, both vaspin expression and secretion were strongly reduced in cells treated with $\mathrm{FSH}$ and PD098059, Compound $\mathrm{C}$ or JSH (Fig. 3, $P<0.05$, $P<0.01, P<0.001)$. We observed that LH with AG490 significantly increased, while LH with JSH decreased vaspin expression and secretion (Fig. $3, P<0.05$ ).

The expression and secretion of vaspin under insulin with all investigated inhibitors were at the same levels. We observed that IGF-1 with LY29402 significantly decreased vaspin levels, while IGF-1 with JSH increased both vaspin expression and secretion (Fig. $4, P<0.05$, $P<0.01, P<0.001)$.

We showed that vaspin expression and concentration in the culture medium were higher in E2 with AG490 and $\mathrm{P} 4$ with Compound $\mathrm{C}$ treatments (Fig. 5, $P<0.05$, $P<0.01, P<0.001)$. In other cases, levels of vaspin were blocked by inhibitors, suggesting activation of these kinases in the regulation of vaspin in the ovary (Fig. 5). Additionally, we observed that all the inhibitors we used had no effect on vaspin expression and secretion.

\section{Discussion}

Vaspin is a recently discovered visceral adipose tissuederived factor that exhibits insulin-sensitising effects, since its administration to obese rodents ameliorated certain obesity-associated disorders (Hida et al. 2005). However, it is unknown whether vaspin has an effect on reproduction. In this study, we report for the first time that vaspin is expressed in the ovary, more specifically in porcine ovarian follicles. Immunohistochemistry analysis documented vaspin protein in ovarian granulosa, theca, cells and cumulus, oocytes as well as in WAT cells. Results of our data showed that vaspin expression is dependent on the breed of pigs (fat mobilisation), days of the oestrous cycle and its regulation by gonadotropin, insulin, IGF-1 and steroids hormones, interestingly through the activation of different kinases such as JAK/ Stat, ERK1/2, PI3K and AMPK, as well as the NF- $\mathrm{KB}$ factor.

By comparing levels of vaspin between both pig breeds, fat MS and lean LW, we observed significantly higher expression of vaspin in the ovarian follicles and WAT collected from MS compared to LW, which may reflect the different strategies employed by the two breeds to achieve prolificacy and fat mobilisation. Body weight, length, weight and width of uterine horns, as well as surface area and weight of endometrium and ovaries are greater in LW gilts (Bazer et al. 1988), while MS is characterised by an abundance of fat. Thus, our results indicate that vaspin levels are strongly dependent on fat quantity. Data of González et al. (2009) documented 

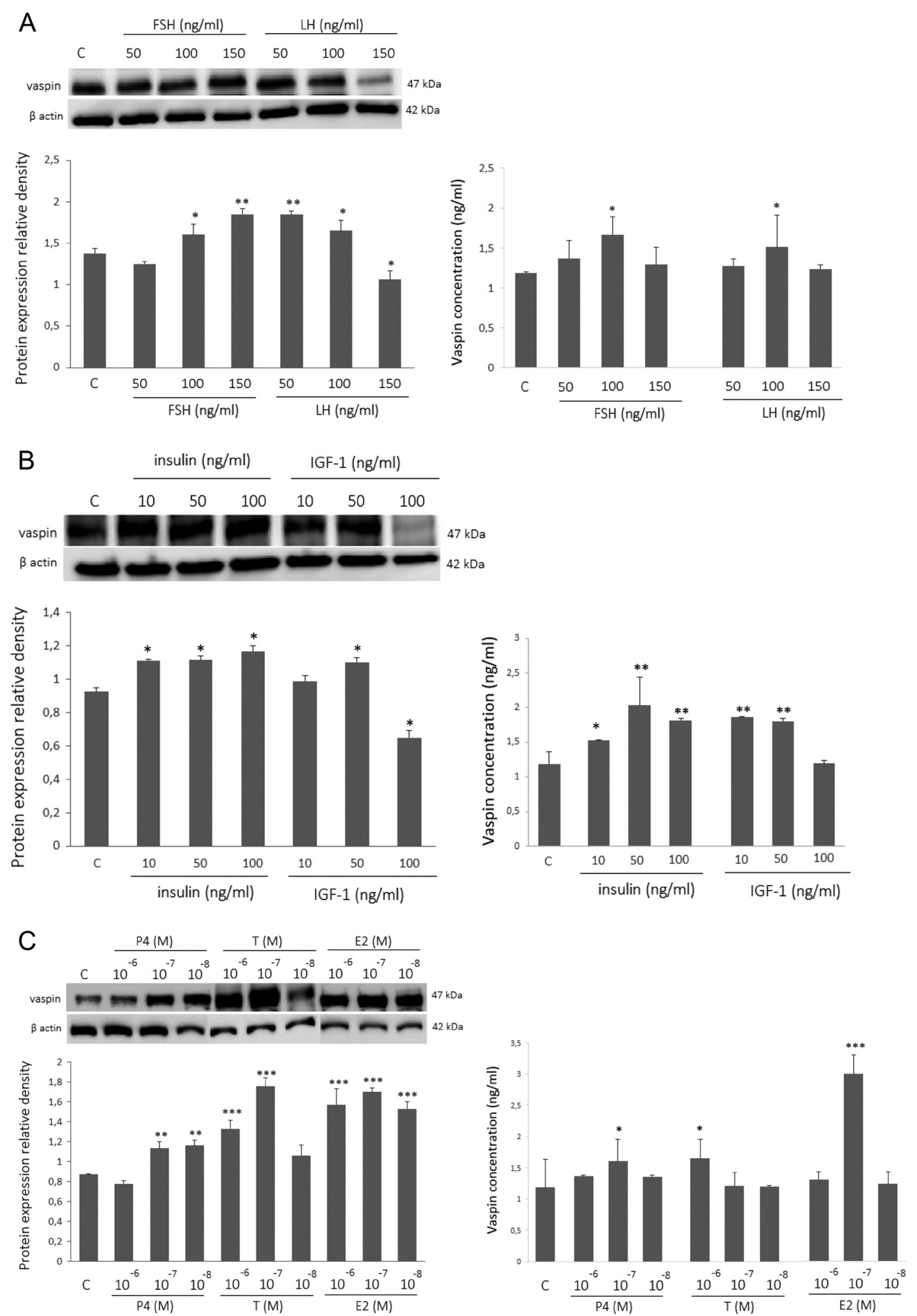

Figure 2 Effect of (A) follicle-stimulating hormone (FSH) and luteinizing hormone (LH) at doses 50-150 ng/mL, (B) insulin and insulin-like growth factor type 1 (IGF-1) at doses 10-100 ng/mL and (C) steroids progesterone (P4), testosterone (T) and oestradiol (E2) at doses $10^{-8}-10^{-6} \mathrm{M}^{\circ}$ on vaspin protein expression and concentration in the culture medium of ovarian cells from Large White pigs. Statistical analysis was carried out using one-way ANOVA, followed by Tukey's test (GraphPad Software) of four independent cultures. Statistical significances are indicated by ${ }^{*} P<0.05,{ }^{* *} P<0.01$ and ${ }^{* * *} P<0.001$. 
that vaspin levels in WAT in female rats are mediated by serum levels of leptin, which is the first fat cell-derived hormone. Multivariate regression analysis revealed increased body fat mass as the strongest predictor for vaspin gene expression (Klöting et al. 2006), confirming that expression of this adipokine is induced by increased abundance of fat, impaired glycaemic control and metabolic syndrome and as such, may represent a compensatory molecule in obesity and related disorders such as inflammation and insulin resistance (Wada 2008). A number of studies have investigated that vaspin levels decreased significantly after weight loss and fat reduction, for example after bariatric surgery or lifestyle intervention (Handisurya et al. 2010, Golpaie et al. 2011, Vink et al. 2017).

To our knowledge, the presented data showed for the first time expression of vaspin in the ovarian tissue. Strong immunolocalisation of vaspin protein was observed in granulosa, cumulus and theca cells, as well as in oocytes. We have shown that in similar concentration of vaspin in plasma and $\mathrm{FF}$, both mRNA and protein expression of vaspin in the ovarian follicles are decreased in LW pigs during days of the oestrous cycle compared to MS pigs, in which vaspin levels were significantly higher at 16-18 days of the oestrous cycle, reflecting possibly different strategies in reproduction. MS breed reaches
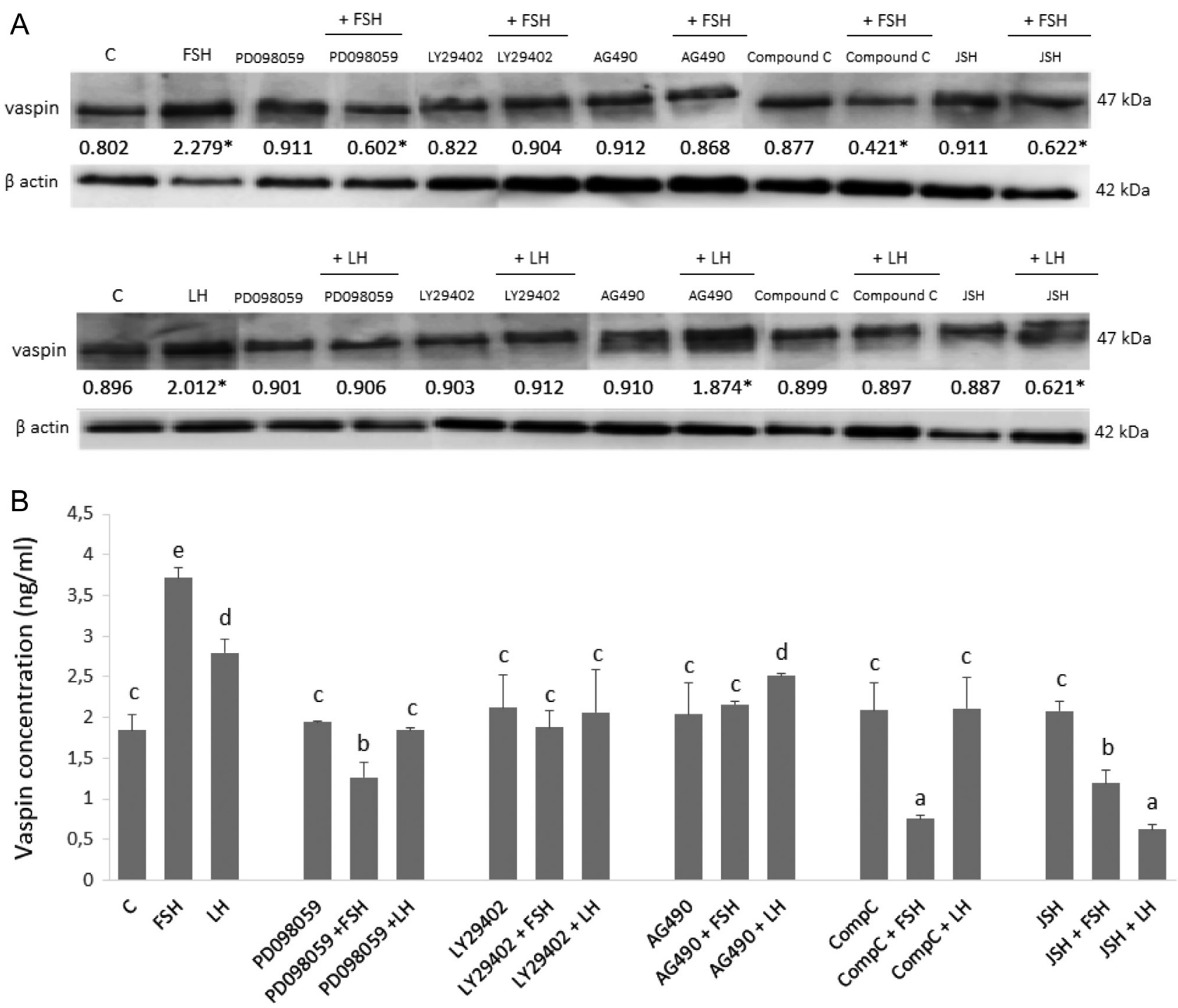

Figure 3 Effect of follicle-stimulating hormone (FSH) and luteinizing hormone ( $\mathrm{LH}$ ) at dose $100 \mathrm{ng} / \mathrm{mL}$ on protein expression (A) and concentration in medium (B) of vaspin in cultured ovarian cells, at 10-12 days of the oestrous cycle of Large White pigs after using pharmacological inhibitors of Janus kinase (JAK/STAT; AG490, $50 \mu \mathrm{M})$, extracellular signal-regulated kinase (MAPK/ERK1/2; PD098059, 50 $\mu$ M), phosphatidylinositol 3'-kinase (PI3K; LY294002, $10 \mu \mathrm{M}$ ), adenosine 5'-monophosphate-activated protein kinase (AMPK; Compound C, $10 \mu \mathrm{M})$ and nuclear factor- $\mathrm{kB}(\mathrm{NF}-\mathrm{\kappa B}$; JSH-23, $50 \mu \mathrm{M})$. Statistical analysis was carried out using one-way or two-way ANOVA, followed by Tukey's test (GraphPad Software) of five independent cultures. Statistical significances are indicated by ${ }^{*} P<0.05,{ }^{* *} P<0.01$ and ${ }^{* * *} P<0.001$. 

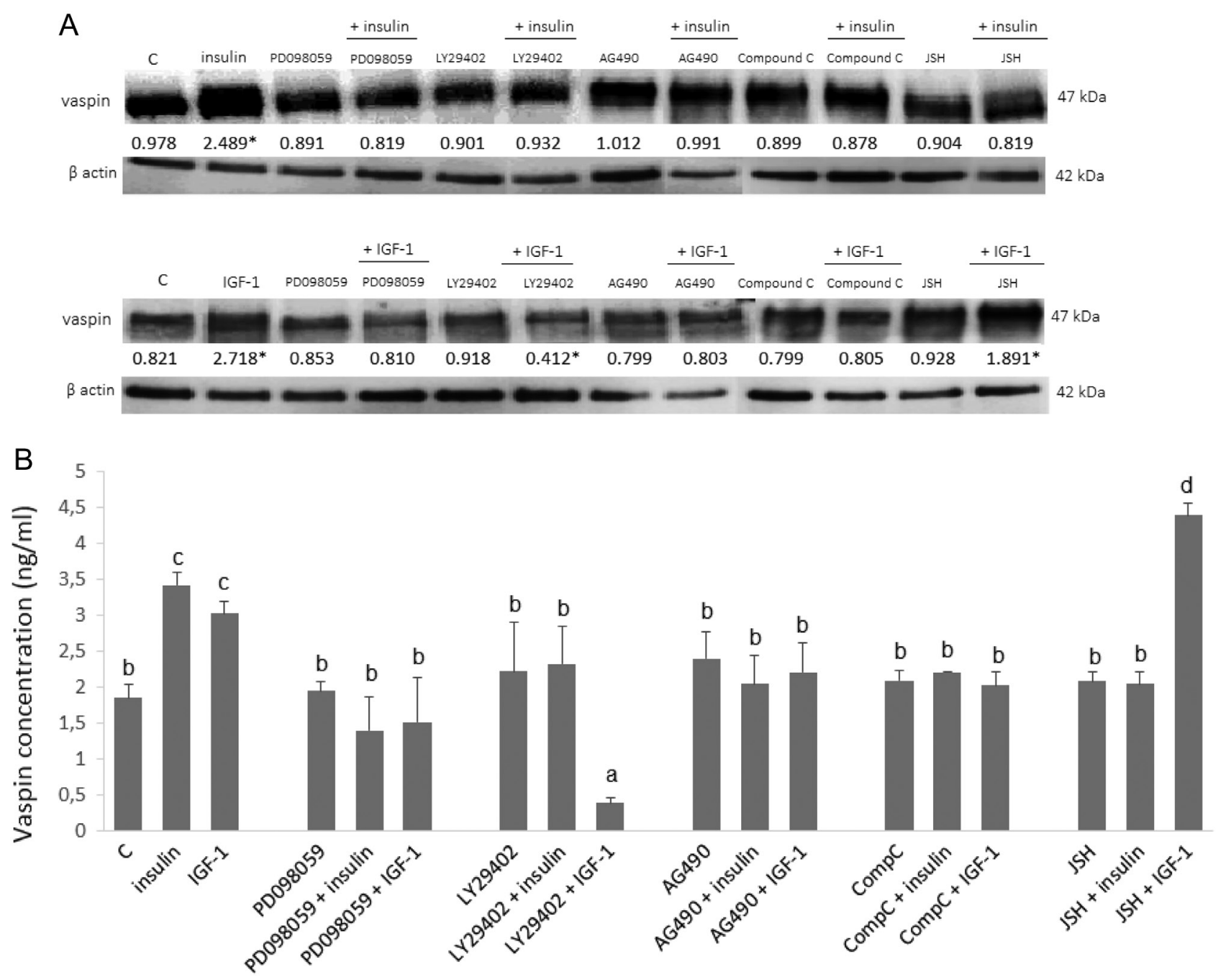

Figure 4 Effect of insulin and insulin-like growth factor type 1 (IGF-1) at dose $50 \mathrm{ng} / \mathrm{mL}$ on protein expression (A) and concentration in medium (B) of vaspin in cultured ovarian cells, at 10-12 days of the oestrous cycle of Large White pigs after using pharmacological inhibitors of Janus kinase (JAK/STAT; AG490, $50 \mu \mathrm{M}$ ), extracellular signal-regulated kinase (MAPK/ERK1/2; PD098059, 50 $\mu \mathrm{M})$ ), phosphatidylinositol 3'-kinase (PI3K; LY294002, $10 \mu \mathrm{M}$ ), adenosine 5'-monophosphate-activated protein kinase (AMPK; Compound C, $10 \mu \mathrm{M}$ ) and nuclear factor- $\mathrm{kB}$ (NF-kB; JSH-23, $50 \mu \mathrm{M}$ ). Statistical analysis was carried out using one-way or two-way ANOVA, followed by Tukey's test (GraphPad Software) of five independent cultures. Statistical significances are indicated by $* P<0.05,{ }^{* *} P<0.01$ and ${ }^{* * *} P<0.001$.

maturity very fast, where the number of oestrous cycles and ovulation rate are much higher than LW (data not yet published). Additionally, sows carry traits that make them one of the most reproductive breeds in the world. Previous studies have compared follicular development between MS and LW (Dufour \& Mariana 1993). In gilts with low recruitment of antral follicles, as observed in MS, ovulatory follicles can be selected from a wide range of size classes containing few follicles. Whereas, in gilts with high recruitment of antral follicles, as observed in LW, ovulatory follicles appear to be selected from a narrow range of mostly large size classes. In addition to a decrease in the number of follicular size classes, increased level of atresia seems to limit ovulations in such breeds. It is still not known whether or not FSH is involved in the selection of ovulatory follicles. However, in the absence of equine chorionic gonadotropin (eCG), few LH-sensitive follicles are recruited and selected in the LW compared to MS. On the other hand, recruitment and selection have become identical in the two breeds after eCG injection. The process of ovulation in pigs implies different strategies for recruitment, selection and atresia according to the breed (Dufour \& Mariana 1993). Additionally, Miller et al. (1998) documented higher FF E2 concentrations observed in preovulatory follicles, as well as number of follicles in the ovaries collected from MS. Moreover, Driancourt and Terqui (1996) also reported that follicles from hyperprolific animals secreted more E2 than those from control animals. Taken together, higher levels on E2 and different ovulatory rate can be factors that induce vaspin ovarian levels during oestrous cycle in MS. 

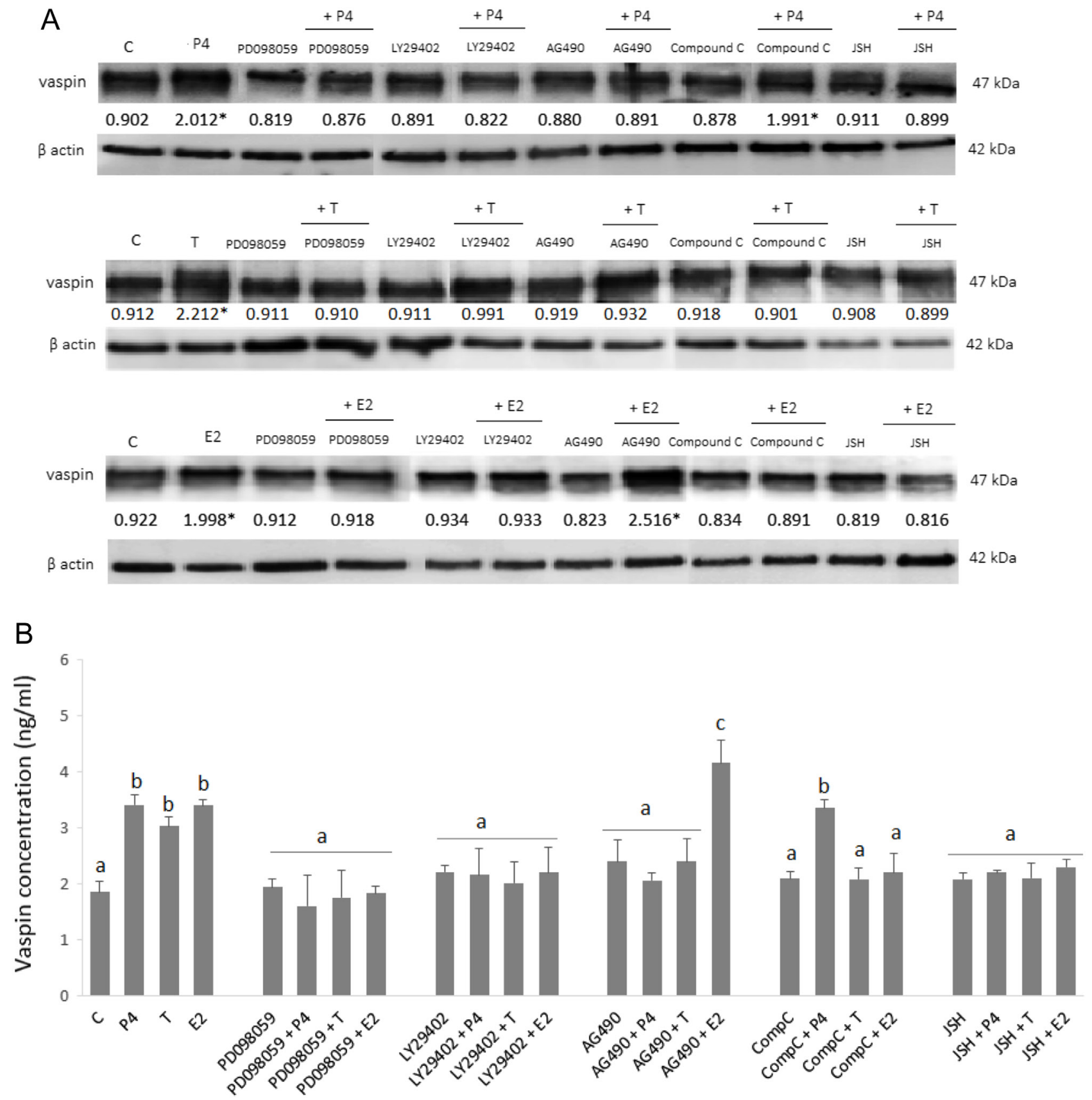

Figure 5 Effect of progesterone (P4), testosterone (T) and oestradiol (E2) at dose $10^{-7} \mathrm{M}$ on protein expression (A) and concentration in medium (B) of vaspin in cultured ovarian cells, at 10-12 days of the oestrous cycle of Large White pigs after using pharmacological inhibitors of Janus

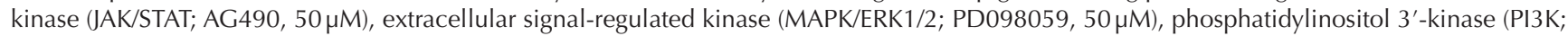

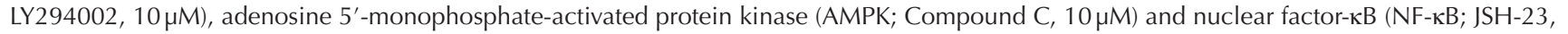
$50 \mu \mathrm{M})$. Statistical analysis was carried out using one-way or two-way ANOVA, followed by Tukey's test (GraphPad Software) of five independent cultures. Statistical significances are indicated by ${ }^{*} P<0.05,{ }^{* *} P<0.01$ and ${ }^{* * *} P<0.001$.

Based on our findings that indicated differences in vaspin expression during the oestrous cycle, we focused on determining the factors that can regulate vaspin expression in the ovary. Results of our in vitro study clearly showed that gonadotropin, insulin, IGF-1 and steroids (P4, T and E2) significantly increased vaspin protein expression in the ovarian follicles and secretion to the culture medium. However, both LH and IGF-1 at higher doses 150 and $100 \mathrm{ng} / \mathrm{mL}$, respectively, have inhibitory effect on vaspin protein expression, suggesting dose-dependent effect of these hormones. Similar results were observed in response to other adipokines such as resistin, where IGF-1 decreased in a dosedependent manner the resistin level in porcine ovarian 
cells (Rak et al. 2015b). To our knowledge, our results demonstrated for the first time that both gonadotropins regulate vaspin expression. However, previous studies have reported that gonadotropins are involved in the regulation of expression of other adipokines in ovarian cells, such as leptin (Siawrys \& Smolinska 2013), adiponectin and its receptors (Chabrolle et al. 2007, Wickham et al. 2013), apelin and its receptor (APJ) (Shimizu et al. 2009) and resistin (Rak et al. 2015b). Several studies showed that the hormonal interactions of the hypothalamic-pituitary-ovarian axis are accountable for normal ovarian activity. FSH plays a role in regulating the number of ovarian follicles that mature and in Gc proliferation and apoptosis (Wheaton et al. 1998), whereas LH is the principal luteotrophic signal in pigs, cows and sheep and is necessary for normal development of the corpus luteum and maintenance of its function (Gregoraszczuk 1991, Stouffer 2006). For the first time, these observations suggest that gonadotropins are also involved in the regulation of vaspin expression in ovarian follicles. Next, we observed that insulin and IGF-1 also have stimulatory effect on vaspin expression. Our results are in agreement with the data that demonstrated that vaspin expression in WAT was induced by insulin (Hida et al. 2005) and metformin, an insulin sensitiser (González et al. 2009). Previously, several studies documented connection between vaspin expression and steroids hormone. For example, vaspin serum levels were significantly enhanced in women using oral contraceptives (von Loeffelholz et al. 2010). Additionally, combined therapies using metformin and oestrogen/progestogen enhanced vaspin serum levels in non-obese women with hyperinsulinaemic androgen excess (Ibáñez et al. 2009). Elevated serum levels and adipose tissue expression were also observed in obese women with PCOS, where dehydroepiandrosterone sulphate significantly induced vaspin protein expression and secretion in adipose tissue explants (Tan et al. 2008).

Finally, we investigated the molecular mechanism involved in the regulation of vaspin in the ovarian cells in response to gonadotropins, insulin, IGF-1 and steroids by blocking different kinases activation. We observed that specific inhibitors of kinases JAK/Stat (AG490), ERK1/2 (PD098059), PI3K (LY294002) and AMPK (Compound C) as well as factor NF-KB (JSH-23) significantly changed the levels of vaspin, suggesting that expression of vaspin in the ovarian cells can be mediated via different kinases activation. To support these observations, Tang et al. (2014) found that resistin mRNA expression in 3T3-L1 adipocytes was mediated via ERK MAPK, JNK, PI3K and JAK2 pathways in response to endothelin 1. Similarly, endothelin 1 regulates adiponectin gene expression and secretion in 3T3-L1 via ERK1/2 and PKA activation (Juan et al. 2007). Results of our study are consistent with the previous data showing that resistin expression was regulated by $17 \beta-\mathrm{E} 2$ (Chen et al. 2006) or IGF-1 (Chen et al. 2005) by activation of ERK pathway. To our knowledge, phosphorylation of JAK/Stat, ERK1/2, $\mathrm{PI} 3 \mathrm{~K}$ or AMPK is necessary to ovarian physiology and its function, including steroid hormones secretion, proliferation, embryogenesis, cell migration and apoptosis (Makarevich et al. 2000, Mertens-Walker et al. 2010, Rak et al. 2017b). Additionally, it is interesting in our findings that several kinases are also activated to regulate vaspin expression in ovarian cells.

In summary, our data indicated that (a) vaspin expression was significantly higher in the ovarian follicles and adipose tissue from MS compared to LW; (b) mRNA and protein expression of vaspin as well as its concentration in plasma and FF decreased in ovarian follicles of LW pigs during days of the oestrous cycle, while the opposite results were observed in ovarian follicles from MS pigs, where vaspin mRNA expression was significantly higher at 16-18 days of the oestrous cycle; (c) vaspin is present not only in granulosa, theca and cumulus cells but also in oocytes; (d) expression of vaspin was increased by gonadotropin, insulin, IGF-1 and steroids hormone and (e) different kinases such as JAK/Stat, ERK1/2, PI3K and AMPK, as well as factor NF-KB, were activated in vaspin regulation in the cultured ovarian cells. Further studies are necessary to better understand the role of vaspin on reproduction and ovarian physiology, for example steroid secretion, cell proliferation/apoptosis and oocyte maturation, thus providing new insights into the pathology of ovaries like PCOS. For example, recent published studies clearly documented that vaspin could be a potential novel biomarker for the prediction and early diagnosis of pregnancy pathology (Mm et al. 2014, Mierzyński et al. 2019).

\section{Declaration of interest}

The authors declare that there is no conflict of interest that could be perceived as prejudicing the impartiality of the research reported.

\section{Funding}

Grant support: National Science Centre, Poland (Grant HARMONIA no. 2016/22/M/NZ9/00316).

\section{Acknowledgements}

The authors thank Christelle Rame and Eric Venturic for their technical support. The present publication contains parts of Patrycja Kurowska's PhD dissertation.

\section{References}

Akins EL \& Morrissette MC 1968 Gross ovarian changes during estrous cycle of swine. American Journal of Veterinary Research 29 1953-1957. Bazer FW, Thatcher WW, Martinat-Botte F \& Terqui M 1988 Sexual maturation and morphological development of the reproductive tract in 
large white and prolific Chinese Meishan pigs. Journal of Reproduction and Fertility 83 723-728. (https://doi.org/10.1530/jrf.0.0830723)

Bidanel JP, Caritez JC \& Legault C 1990 Estimation of crossbreeding parameters between Large White and Meishan porcine breeds. II. Growth before weaning and growth of females during the growing and reproductive periods. Genetics Selection Evolution 22 431. (https://doi. org/10.1186/1297-9686-22-4-431)

Cakal E, Ustun Y, Engin-Ustun Y, Ozkaya M \& Kilinç M 2011 Serum vaspin and C-reactive protein levels in women with polycystic ovaries and polycystic ovary syndrome. Gynecological Endocrinology 27 491-495. (https://doi.org/10.3109/09513590.2010.501874)

Chabrolle C, Tosca L \& Dupont J 2007 Regulation of adiponectin and its receptors in rat ovary by human chorionic gonadotrophin treatment and potential involvement of adiponectin in granulosa cell steroidogenesis. Reproduction 133 719-731. (https://doi.org/10.1530/REP-06-0244)

Chen YH, Hung PF \& Kao YH 2005 IGF-I downregulates resistin gene expression and protein secretion. American Journal of Physiology: Endocrinology and Metabolism 288 E1019-E1027. (https://doi. org/10.1152/ajpendo.00325.2004)

Chen YH, Lee MJ, Chang HH, Hung PF \& Kao YH 2006 17beta-Estradiol stimulates resistin gene expression in 3T3-L1 adipocytes via the estrogen receptor, extracellularly regulated kinase, and CCAAT/enhancer binding protein-alpha pathways. Endocrinology 147 4496-4504. (https://doi. org/10.1210/en.2005-1655)

Driancourt MA \& Terqui M 1996 Follicular growth and maturation in hyperprolific and large white sows. Journal of Animal Science 74 2231-2238. (https://doi.org/10.2527/1996.7492231x)

Dufour JJ \& Mariana JC 1993 Comparative follicular development in Meishan and Large White gilts during prepubertal periods and its relation to hormonal stimulation. Biology of Reproduction $\mathbf{4 8}$ 1020-1025. (https://doi.org/10.1095/biolreprod48.5.1020)

Golpaie A, Tajik N, Masoudkabir F, Karbaschian Z, Talebpour M, Hoseini M \& Hosseinzadeh-Attar MJ 2011 Short-term effect of weight loss through restrictive bariatric surgery on serum levels of vaspin in morbidly obese subjects. European Cytokine Network 22 181-186. (https://doi. org/10.1684/ecn.2011.0295)

González CR, Caminos JE, Vázquez MJ, Garcés MF, Cepeda LA, Angel A, González AC, Garcia-Rendueles ME, Sangiao-Alvarellos S, López M et al. 2009 Regulation of visceral adipose tissue-derived serine protease inhibitor by nutritional status, metformin, gender and pituitary factors in rat white adipose tissue. Journal of Physiology 587 3741-3750. (https:// doi.org/10.1113/jphysiol.2009.172510)

Gregoraszczuk E 1991 The interaction of testosterone and gonadotropins in stimulating estradiol and progesterone secretion by cultures of corpus luteum cells isolated from pigs in early and midluteal phase. Endocrinologia Japonica 38 229-237. (https://doi.org/10.1507/ endocrj1954.38.229)

Haley CS, d'Agaro E \& Ellis M 1992 Genetic components of growth and ultrasonic fat depth traits in Meishan and Large White pigs and their reciprocal crosses. Animal Production 54 105-115. (https://doi. org/10.1017/S0003356100020626)

Handisurya A, Riedl M, Vila G, Maier C, Clodi M, Prikoszovich T, Ludvik B, Prager G, Luger A \& Kautzky-Willer A 2010 Serum vaspin concentrations in relation to insulin sensitivity following RYGB-induced weight loss. Obesity Surgery 20 198-203. (https://doi.org/10.1007/ s11695-009-9882-y)

Heiker JT 2014 Vaspin (serpinA12) in obesity, insulin resistance, and inflammation. Journal of Peptide Science 20 299-306. (https://doi. org/10.1002/psc.2621)

Hida K, Wada J, Zhang H, Hiragushi K, Tsuchiyama Y, Shikata K \& Makino H 2000 Identification of genes specifically expressed in the accumulated visceral adipose tissue of OLETF rats. Journal of Lipid Research 41 1615-1622.

Hida K, Wada J, Eguchi J, Zhang H, Baba M, Seida A, Hashimoto I, Okada T, Yasuhara A, Nakatsuka A et al. 2005 Visceral adipose tissue-derived serine protease inhibitor: a unique insulin-sensitizing adipocytokine in obesity. PNAS 102 10610-10615. (https://doi. org/10.1073/pnas.0504703102)

Ibáñez L, López-Bermejo A, Díaz M, Enríquez G, del Río L \& de Zegher F 2009 Low-dose pioglitazone and low-dose flutamide added to metformin and oestro-progestagens for hyperinsulinaemic women with androgen excess: add-on benefits disclosed by a randomized double-placebo study over 24 months. Clinical Endocrinology 71 351-357. (https://doi. org/10.1111/j.1365-2265.2008.03472.x)

Juan CC, Chuang TY, Chang CL, Huang SW \& Ho LT 2007 Endothelin-1 regulates adiponectin gene expression and secretion in 3T3-L1 adipocytes via distinct signaling pathways. Endocrinology $\mathbf{1 4 8}$ 1835-1842. (https://doi.org/10.1210/en.2006-0654)

Klöting N, Berndt J, Kralisch S, Kovacs P, Fasshauer M, Schön MR, Stumvoll M \& Blüher M 2006 Vaspin gene expression in human adipose tissue: association with obesity and type 2 diabetes. Biochemical and Biophysical Research Communications 339 430-436. (https://doi. org/10.1016/j.bbrc.2005.11.039)

Klöting N, Kovacs P, Kern M, Heiker JT, Fasshauer $M$, Schön MR, Stumvoll M, Beck-Sickinger AG \& Blüher M 2011 Central vaspin administration acutely reduces food intake and has sustained blood glucose-lowering effects. Diabetologia 54 1819-1823. (https://doi. org/10.1007/s00125-011-2137-1)

Koiou E, Tziomalos K, Dinas K, Katsikis I, Kalaitzakis E, Delkos D, Kandaraki EA \& Panidis D 2011a The effect of weight loss and treatment with metformin on serum vaspin levels in women with polycystic ovary syndrome. Endocrine Journal 58 237-246. (https://doi.org/10.1507/ endocrj.K10E-330)

Koiou E, Dinas K, Tziomalos K, Toulis K, Kandaraki EA, Kalaitzakis E, Katsikis I \& Panidis D 2011b The phenotypes of polycystic ovary syndrome defined by the 1990 diagnostic criteria are associated with higher serum vaspin levels than the phenotypes introduced by the 2003 criteria. Obesity Facts 4 145-150. (https://doi.org/10.1159/000327935)

Kolodziejczyk J, Gertler A, Leibovich H, Rzasa J \& Gregoraszczuk EL 2003 Synergistic action of growth hormone and insulin-like growth factor I (IGF-I) on proliferation and estradiol secretion in porcine granulosa and theca cells cultured alone or in coculture. Theriogenology 60 559-570. (https://doi.org/10.1016/S0093-691X(03)00032-3)

Makarevich A, Sirotkin A, Chrenek P, Bulla J \& Hetenyi L 2000 The role of IGF-I, cAMP/protein kinase A and MAP-kinase in the control of steroid secretion, cyclic nucleotide production, granulosa cell proliferation and preimplantation embryo development in rabbits. Journal of Steroid Biochemistry and Molecular Biology 73 123-133. (https://doi. org/10.1016/S0960-0760(00)00067-4)

Mertens-Walker I, Bolitho C, Baxter RC \& Marsh DJ 2010 Gonadotropininduced ovarian cancer cell migration and proliferation require extracellular signal-regulated kinase $1 / 2$ activation regulated by calcium and protein kinase C\{delta\}. Endocrine-Related Cancer 17 335-349. (https://doi.org/10.1677/ERC-09-0152)

Mierzyński R, Poniedziałek-Czajkowska E, Dłuski D, Patro-Małysza J, Kimber-Trojnar Ż, Majsterek M \& Leszczyńska-Gorzelak B 2019 Nesfatin-1 and vaspin as potential novel biomarkers for the prediction and early diagnosis of gestational diabetes mellitus. International Journal of Molecular Sciences 20 E159. (https://doi.org/10.3390/ijms20010159)

Miller AT, Picton HM, Craigon J \& Hunter MG 1998 Follicle dynamics and aromatase activity in high-ovulating Meishan sows and in Large-White hybrid contemporaries. Biology of Reproduction 58 1372-1378. (https:// doi.org/10.1095/biolreprod58.6.1372)

Mm WQ, Fan J, Khor S, Song M, Hong W \& Dai X 2014 Serum vaspin levels and vaspin mRNA expression in subcutaneous adipose tissue in women with gestational diabetes mellitus. European Journal of Obstetrics, Gynecology, and Reproductive Biology 182 98-101. (https:// doi.org/10.1016/j.ejogrb.2014.09.008)

Pierre $P$, Froment $P$, Nègre $D$, Ramé $C$, Barateau V, Chabrolle $C$, Lecomte $P$ \& Dupont J 2009 Role of adiponectin receptors, AdipoR1 and AdipoR2, in the steroidogenesis of the human granulosa tumor cell line, KGN. Human Reproduction 24 2890-2901. (https://doi.org/10.1093/humrep/ dep292)

Rak A \& Gregoraszczuk EL 2008 Modulatory effect of ghrelin in prepubertal porcine ovarian follicles. Journal of Physiology and Pharmacology 59 781-793.

Rak A, Drwal E, Wróbel A \& Gregoraszczuk Et 2015a Resistin is a survival factor for porcine ovarian follicular cells. Reproduction 150 343-355. (https://doi.org/10.1530/REP-15-0255)

Rak A, Drwal E, Karpeta A \& Gregoraszczuk Et 2015b Regulatory role of gonadotropins and local factors produced by ovarian follicles on in vitro resistin expression and action on porcine follicular steroidogenesis. Biology of Reproduction 92142 (https://doi.org/10.1095/ biolreprod.115.128611) 
Rak A, Drwal E, Rame C, Knapczyk-Stwora K, Słomczyńska M, Dupont J \& Gregoraszczuk EL 2017a Expression of apelin and apelin receptor (APJ) in porcine ovarian follicles and in vitro effect of apelin on steroidogenesis and proliferation through APJ activation and different signaling pathways. Theriogenology 96 126-135. (https://doi.org/10.1016/j. theriogenology.2017.04.014)

Rak A, Mellouk N, Froment P \& Dupont J 2017b Adiponectin and resistin: potential metabolic signals affecting hypothalamo-pituitary gonadal axis in females and males of different species. Reproduction 153 R215-R226. (https://doi.org/10.1530/REP-17-0002)

Rak-Mardyla A \& Gregoraszczuk EL 2010 ERK $1 / 2$ and PI-3 kinase pathways as a potential mechanism of ghrelin action on cell proliferation and apoptosis in the porcine ovarian follicular cells. Journal of Physiology and Pharmacology 61 451-458.

Reverchon M, Bertoldo MJ, Ramé C, Froment P\& Dupont J 2014 Chemerin (RARRES2) decreases in vitro granulosa cell steroidogenesis and blocks oocyte meiotic progression in bovine species. Biology of Reproduction 90 102. (https://doi.org/10.1095/biolreprod.113.117044)

Richards JS, Liu Z, Kawai T, Tabata K, Watanabe H, Suresh D, Kuo FT, Pisarska MD \& Shimida M 2012 Adiponectin and its receptors modulate granulosa cell and cumulus cell functions, fertility, and early embryo development in the mouse and human. Fertility and Sterility 98 471-9. e1. (https://doi.org/10.1016/j.fertnstert.2012.04.050)

Roche J, Ramé C, Reverchon M, Mellouk N, Rak A, Froment P \& Dupont J 2017 Apelin (APLN) regulates progesterone secretion and oocyte maturation in bovine ovarian cells. Reproduction 153 589-603. (https:// doi.org/10.1530/REP-16-0677)

Rojas J, Chávez M, Olivar L, Rojas M, Morillo J, Mejías J, Calvo M \& Bermúdez V 2014 Polycystic ovary syndrome, insulin resistance, and obesity: navigating the pathophysiologic labyrinth. International Journal of Reproductive Medicine 2014 719050: doi:10.1155/2014/719050.

Schilffarth S, Antoni B, Schamas D, Meyer HH \& Berisha B 2009 The expression of apelin and its receptor APJ during different physiological stages in the bovine ovary. International Journal of Biological Sciences $\mathbf{5}$ 344-350. (https://doi.org/10.7150/ijbs.5.344)

Serra JJ, Ellis M \& Haley CS 1992 Genetic components of carcass and meat quality traits in Meishan and Large White pigs and their reciprocal crosses. Animal Production 54 117-127. (https://doi.org/10.1017/ S0003356100020638)

Shimizu T, Kosaka N, Murayama C, Tetsuka M \& Miyamoto A 2009 Apelin and APJ receptor expression in granulosa and theca cells during different stages of follicular development in the bovine ovary: involvement of apoptosis and hormonal regulation. Animal Reproduction Science 116 28-37. (https://doi.org/10.1016/j.anireprosci.2009.01.009)

Shirasuna K, Shimizu T, Sayama K, Asahi T, Sasaki M, Berisha B, Schams D \& Miyamoto A 2008 Expression and localization of apelin and its receptor $\mathrm{APJ}$ in the bovine corpus luteum during the estrous cycle and prostaglandin F2alpha-induced luteolysis. Reproduction 135 519-525. (https://doi.org/10.1530/REP-07-0409)

Siawrys G \& Smolinska N 2013 In vitro effects of luteinizing hormone, progesterone and oestradiol-17 $\beta$ on leptin gene expression and leptin secretion by porcine luteal cells obtained in early pregnancy. Journal of Physiology and Pharmacology 64 513-520.

Silva JR, Figueiredo JR \& van den Hurk R 2009 Involvement of growth hormone $(\mathrm{GH})$ and insulin-like growth factor (IGF) system in ovarian folliculogenesis. Theriogenology $71 \quad 1193-1208 . \quad$ (https://doi. org/10.1016/j.theriogenology.2008.12.015)

Stoklosowa S, Bahr J \& Gregoraszczuk E 1978 Some morphological and functional characteristics of cells of the porcine theca interna in tissue culture. Biology of Reproduction 19 712-719. (https://doi.org/10.1095/ biolreprod19.4.712)
Stouffer RL 2006 Structure, function, and regulation of the corpus luteum. In Physiology of Reproduction, pp 475-527. Eds E Knobil \& JD Neill. San Diego: Elsevier Academic Press.

Tan BK, Heutling D, Chen J, Farhatullah S, Adya R, Keay SD, Kennedy CR, Lehnert H \& Randeva HS 2008 Metformin decreases the adipokine vaspin in overweight women with polycystic ovary syndrome concomitant with improvement in insulin sensitivity and a decrease in insulin resistance. Diabetes 57 1501-1507. (https://doi.org/10.2337/db08-0127)

Tang YC, Liu CW, Chang HH, Juan CC, Kuo YC, Kao CC, Huang YM \& Kao YH 2014 Endothelin-1 stimulates resistin gene expression. Endocrinology 155 854-864. (https://doi.org/10.1210/en.2013-1847)

Tersigni C, Di Nicuolo F, D'Ippolito S, Veglia M, Castellucci M \& Di Simone N 2011 Adipokines: new emerging roles in fertility and reproduction. Obstetrical and Gynecological Survey 66 47-63. (https:// doi.org/10.1097/OGX.0b013e318217b0a4)

Vandesompele J, De Prete K, Pattyn F, Poppe B, Van Roy N, De Paepe A \& Speleman F 2002 Accurate normalization of real-time quantitative RT-PCR data by geometric averaging of multiple internal control genes. Genome Biology 3 research0034.1-research0034.11. (https://doi. org/10.1186/gb-2002-3-7-research0034)

Vink RG, Roumans NJ, Mariman EC \& van Baak MA 2017 Dietary weight loss-induced changes in RBP4, FFA, and ACE predict weight regain in people with overweight and obesity. Physiological Reports 5 e13450. (https://doi.org/10.14814/phy2.13450)

von Loeffelholz C, Möhlig M, Arafat AM, Isken F, Spranger J, Mai K, Randeva HS, Pfeiffer AF \& Weickert MO 2010 Circulating vaspin is unrelated to insulin sensitivity in a cohort of nondiabetic humans. European Journal of Endocrinology 162 507-513. (https://doi. org/10.1530/EJE-09-0737)

Wada J 2008 Vaspin: a novel serpin with insulin-sensitizing effects. Expert Opinion on Investigational Drugs 17 327-333. (https://doi. org/10.1517/13543784.17.3.327)

Weiner J, Rohde K, Krause K, Zieger K, Klöting N, Kralisch S, Kovacs P, Stumvoll M, Blüher M, Böttcher Y et al. 2017 Brown adipose tissue (BAT) specific vaspin expression is increased after obesogenic diets and cold exposure and linked to acute changes in DNA-methylation. Molecular Metabolism 6 482-493. (https://doi.org/10.1016/j.molmet.2017.03.004)

Wheaton JE, Meyer RL, Jones RH \& Kramer AJ 1998 Effects of passive immunization using antibody against an alpha-inhibin peptide on folliclestimulating hormone concentrations and litter size in sows. Theriogenology 49 813-822. (https://doi.org/10.1016/S0093-691X(98)00030-2)

Wickham EP, Tao T, Nestler JE \& McGee EA 2013 Activation of the LH receptor up regulates the type 2 adiponectin receptor in human granulosa cells. Journal of Assisted Reproduction and Genetics 30 963-968. (https://doi.org/10.1007/s10815-013-0012-3)

Xu F \& Stouffer RL 2012 Dynamic expression of apelin and its receptor in the primate preovulatory follicle and corpus luteum during the menstrual cycle. Biology of Reproduction 87 (Supplement 1) 169-169. (https://doi. org/10.1093/biolreprod/87.s1.169)

Youn BS, Klöting N, Kratzsch J, Lee N, Park JW, Song ES, Ruschke K, Oberbach A, Fasshauer M, Stumvoll M et al. 2008 Serum vaspin concentrations in human obesity and type 2 diabetes. Diabetes $\mathbf{5 7}$ 372-377. (https://doi.org/10.2337/db07-1045)

Received 21 January 2019

First decision 8 February 2019

Revised manuscript received 30 April 2019

Accepted 7 May 2019 